\title{
Research Paper Management of agribusiness enterprise-an analysis of sheep rearing in Chikkaballapur district of Karnataka state
}

\author{
S. Shabeer ul hasan, M.R. Girish and Mamatha Girish
}

See end of the paper for authors' affiliations

Correspondence to :

S. Shabeer ul hasan Department of Agricultural Marketing, Co-operation and Business Management University of Agricultural Sciences (GKVK), Bengaluru (Karnataka) India
Paper History :

Received : 16.06.2020;

Revised : 13.07.2020;

Accepted : 14.08 .2020
ABSTRACT : The present study was conducted in Bagepalli taluk of Chikkaballapur district of Karnataka state to analyse the backward and forward linkages in sheep rearing; to assess the financial viability of sheep rearing and to identify the constraints in sheep rearing. The primary data for the study was collected from 40 sheep rearers. Majority of the sample sheep rearers used their own money realised from horticultural and agricultural crops for investing in sheep enterprise while some of them, especially women borrowed credit from SHGs. The family members met the labour requirements of sheep rearing. Chelur sheep shandy was the only sheep market located in Bagepalli taluk. It is a popular weekly shandy held every Friday where sheep is traded in large numbers. The total cost incurred and the gross returns realised per annum for rearing a flock size of 61 sheep was Rs. 1,59,577/ - and Rs. 2,74,788/-, respectively, resulting in a net returns of Rs. 1,15,211/-. Among the variable costs, labour was the major cost accounting for about 83 per cent of the total variable cost. The sale of adult sheep accounted for about 75 per cent of the gross returns followed by sale of lambs $(18.76 \%)$, sale of manure (4.13\%), sale of meat (1.95\%), etc. At 12 per cent discount rate, the NPW, BCR and IRR were found to be Rs. 3,56,943.40/-, 1.72 and 53.77per cent, respectively, indicating the financially viability of sheep rearing. Scarcity of water and exploitation by middlemen were the major constraints faced by sheep rearers.

KEY WORDS : Sheep rearing, Backward, Forward linkages, Financial viability, Discounted cash flow analysis, Constraints

How To Cite This PAper : Shabeer ul hasan, S., Girish, M.R. and Girish, Mamatha (2020). Management of agribusiness enterprise-an analysis of sheep rearing in Chikkaballapur district of Karnataka state. Internat. Res. J. Agric. Eco. \& Stat., 11 (2) : 176-184, DOI : 10.15740/HAS/IRJAES/11.2/176-184. Copyright@2020:Hind Agri-Horticultural Society. 